\title{
Limb anomaly and associated conditions: our clinical experience
}

This article was published in the following Dove Press journal:

Pediatric Health, Medicine and Therapeutics

29 March 20II

Number of times this article has been viewed

\author{
Munisamy Ragavan' \\ Uppalu Haripriya' \\ Janarthanam Sarvavinothini ${ }^{2}$ \\ Nagaraja $\mathrm{Rao}^{3}$ \\ Ramamoorthy \\ Gokulkrishnan ${ }^{3}$ \\ 'Department of Pediatric Surgery, \\ ${ }^{2}$ Department of Anesthesia, \\ ${ }^{3}$ Department of Pediatrics, Narayana \\ Medical College and Superspeciality \\ Hospital, Nellore, Andhra Pradesh, \\ India
}

\begin{abstract}
Limb anomalies are a common clinical problem with a various spectrum of involvement. There are many conditions associated with these anomalies. There is a variable extent of involvement in the form of agenesis, overgrowth, and duplication, and there is no standard classification to describe all these lesions. Studying limb anomalies provides insights into limb development which may be useful for etiologic studies and public health monitoring. We pooled our data for $12 \mathrm{limb}$ anomaly cases presenting from January 2008 to May 2009 and investigated their associated conditions. A descriptive system for the nomenclature and classification of congenital limb malformations suitable for clinical, epidemiological, and experimental use is discussed.

Keywords: limb anomaly, phocomelia, amelia
\end{abstract}

\section{Introduction}

Limb anomalies are a common clinical problem. There is no single standard classification and there are many conditions associated with these anomalies. The extent of limb involvement varies from a mild variant of polydactyly to an absent limb. Studying limb anomalies provides insights into limb development which may be useful for etiologic studies and public health monitoring. We pooled our data on limb anomaly cases presenting at our institution and studied the associated conditions. A simplified system for classification of limb malformations which may be suitable for clinical, epidemiological, and experimental use, as well as images of a few interesting cases, are presented.

\section{Methods and materials}

Twelve limb anomaly cases presenting to our hospital from January 2008 to May 2009 were included in this study. We recorded the symptoms and signs of the anomaly and associated clinical conditions by detailed clinical examination and radiological investigation, as necessary. History of exposure to teratogens, occupational history, and socioeconomic status of the parents were investigated for possible causes. Karyotyping was done in feasible cases. The case details are given below and are summarized in Table 1.

\section{Case I}

A seven-month-old female with upper and lower limb deformity was brought in from an orphanage nursery. There was also deformity of the lip and palate. An antenatal history could not be obtained because the baby had been abandoned by her parents. Examination revealed macrocephaly, a depressed nose, mongoloid slant of the eyes, and a bilateral cleft 
Table I Limb anomalies and their associated conditions

\begin{tabular}{lll}
\hline Type of limb anomaly & $\mathbf{n}$ & Associated anomaly \\
\hline Polydactyly & 4 & $\begin{array}{l}\text { Cardiac, duodenal atresia, } \\
\text { Hirschsprung's disease, biliary atresia }\end{array}$ \\
Syndactyly & 3 & $\begin{array}{l}\text { Apert's syndrome } \\
\text { Single-limb phocomelia }\end{array}$ \\
Tetraphocomelia & 3 & Cleft lip, cleft palate, anorectal, cardiac \\
Radial thumb deformity & 2 & $\begin{array}{l}\text { Cleft lip, cleft palate, cardiac } \\
\text { Microtia, cardiac, sacral, anorectal, } \\
\text { tracheoesophageal fistula }\end{array}$ \\
Cleft hand & I & $\begin{array}{l}\text { Pectus excavatum, microtia } \\
\text { Tetra-amelia }\end{array}$ \\
& I & $\begin{array}{l}\text { Ambiguous genitalia, inguinal hernia, } \\
\text { hypospadias, lung hypoplasia }\end{array}$ \\
\hline
\end{tabular}

lip with complete cleft palate. There was no arm or forearm for both upper limbs. The hands were attached to a short stump of arm (Figure 1). There were only four fingers on both hands, with no differentiation of thumb or other digits. There was a constriction band in the right upper limb close to the palm. The lower limbs were short and with genu varum. The tibia of both the lower limbs was short, with an anterior bend in the right one. There was a talipes deformity of the ankle joints. There was syndactyly of the third and fourth toe. Movement of the hip joints was restricted. The cardiovascular and respiratory systems were clinically normal. The echocardiogram was normal, although a PA X-ray chest view showed an abnormal shape of the heart. An infantogram showed a humerus of $3 \mathrm{~cm}$ on both sides, with no radius or ulna in the upper limb, and the all lower limb bones were very short. The karyotype was 46XX, and a molecular genetic analysis showed no genetic defects. The cleft lip was repaired by Millard's technique. One year later, cleft palate surgery was performed. The baby remains under follow-up and her mental development and speech are good. Craniofacial anomalies in the form of a cleft lip and palate and four-limb anomaly were considered to be part of Roberts-SC syndrome.

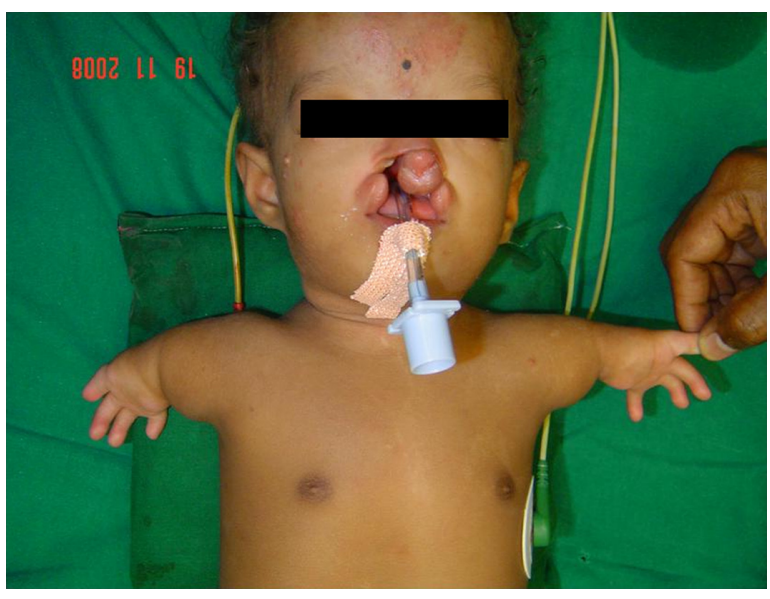

Figure I Absent arm and forearm on both upper limbs with cleft lip and palate.

\section{Case 2}

A 10-day-old baby with absence of all four limbs, abandoned by the parents; was brought in by Christian charity authorities. The baby was accepting feeds and passed meconium and urine on day 1. After seven days, feeds were refused and the baby developed respiratory distress, so was brought in to the pediatric emergency room. Examination revealed absence of all four limbs with ambiguous genitalia characterized by a small phallus and an undeveloped labioscrotal fold (Figure 2). There were no gonads palpable in the labioscrotum. There was a right inguinal hernia. The urethral opening was seen on the ventral surface of the phallus, suggestive of hypospadias. On auscultation, decreased air entry was observed in the right chest. The cardiac system was normal on clinical examination. There was no abdominal distension. The anal opening was normal and admitted a $14 \mathrm{~F}$ red rubber catheter. Intravenous access was made through the jugular vein. The baby died after two hours in intensive care. A vesicourethrogram done after death showed a male-type urethra and a normal-sized urinary bladder. A barium enema showed a normal rectum and sigmoid colon. Magnetic resonance imaging of the chest and abdomen showed right lung hypoplasia and a solid lesion in the right atrium which was found to be a blood clot post mortem. At autopsy, there was only about $2 \mathrm{~cm}$ of right humerus, with the other bones of the upper and lower limbs being absent.

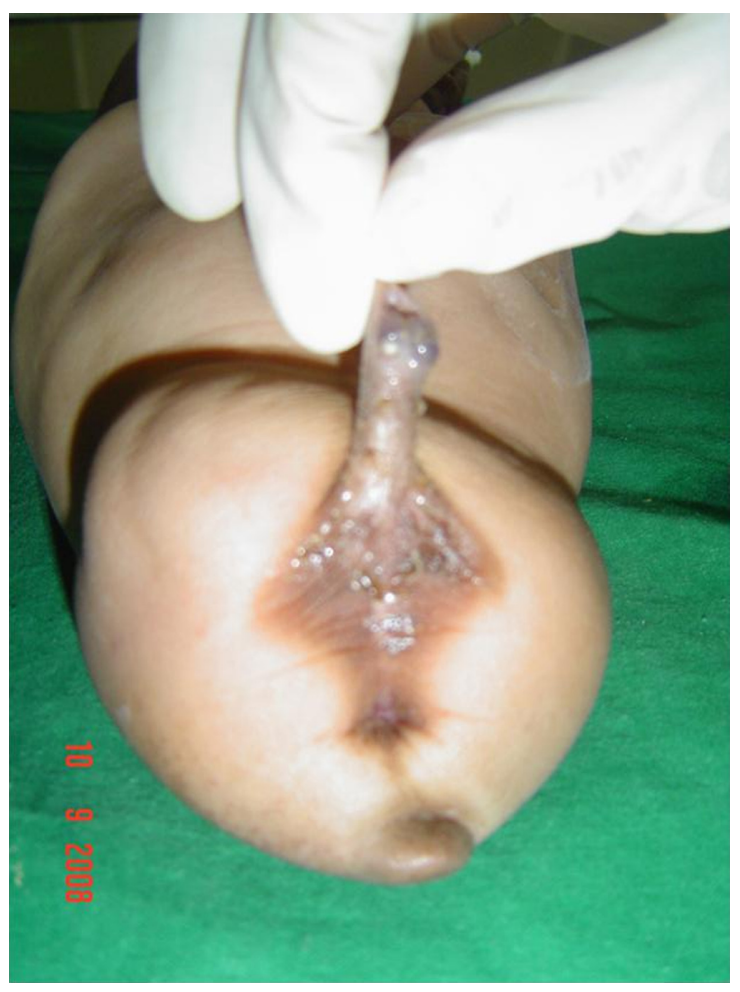

Figure 2 Absence of all four limbs with ambiguous genitalia. 
Autopsy showed a normal brain, heart, gastrointestinal organs, and urinary system. There was right lung hypoplasia. A gonad was present in the left inguinal region, with the right-sided one being absent. Biopsy of the gonad was suggestive of a testis. Karyotyping was 46XY, and molecular genetic analysis could not be done. Four-limb anomaly and lung hypoplasia were deemed to be part of Roberts-SC syndrome in this case.

\section{Case 3}

A nine-year-old child was brought in with an absent right forearm and hand and deformity of the roof of the mouth. Examination revealed right upper limb phocomelia and left hand postaxial syndactyly. There was a cleft of the secondary palate. Cardiovascular and respiratory system were clinically normal. There was no history of any teratogenic exposure during the antenatal period and the occupation of the parents was in agriculture. No further evaluation could be done because this patient did not attend subsequently for surgery.

\section{Case 4}

A two-day-old, full-term, home-delivered female newborn with an absent left lower limb and an absent anal opening was brought to the emergency room. Examination revealed amelia of the left lower limb and a twig of skin attached to the hip region with a narrow pedicle. There was a high anorectal malformation with an absent vaginal opening. Abdominal ultrasonography showed an absent kidney on the left side. A cross-table prone lateral view abdominal $\mathrm{X}$-ray was suggestive of a high anorectal malformation, and hence a sigmoid colostomy was done as an emergency stage 1 operation. Presence of anorectal malformation, absent vaginal opening, and renal agenesis were suggestive of Mayer-Rokitansky-Kuster-Hauser syndrome. The mother was a known seizure disorder patient on carbamazepine therapy.

\section{Case 5}

A three-year-old female child was brought in with a history of absent fingers on both the hands since birth (Figure 3 ). The antenatal period was uneventful and the main occupation of the parents was in the fishing industry. Examination showed pectus excavatum and a pinna deformity. There was an absent middle, ring, and little finger on the left hand and an absent little finger on the right hand called a cleft hand. The associated chest deformity is part of Poland's syndrome, a syndrome characterized by rib and pectal muscle deficiency and breast hypoplasia.

\section{Case 6}

A two-day-old full-term male neonate was brought in with a history of drooling of saliva and vomiting of

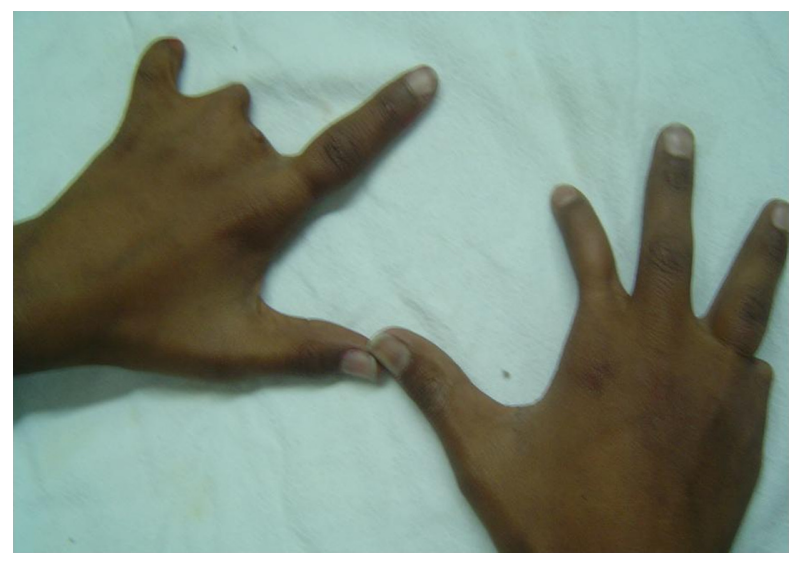

Figure 3 Multiple absent fingers of both hands.

milk since birth. Examination revealed left ear microtia, left radial deviation of the wrist, with hypoplasia of the radius. There was a wide-gap tracheoesophageal fistula (lower pouch fistula and upper blind pouch type). There was an atrial septal defect on echocardiography. All these features were suggestive of VACTERL (vertebral defects, anorectal, cardiac, tracheoesophageal, radial, renal and limb anomalies)/VATER (vertebral defects, anal atresia, esophageal atresia, renal defects, and radial-ray limb deficiency) association. Cervical esophagostomy and gastrostomy was performed, with division and closure of the tracheoesophageal fistula. The baby died after three days due to sepsis.

\section{Case 7}

A 10-day-old preterm, very low birth weight female baby was brought with bilious vomiting and abdominal distension. The baby weighed $700 \mathrm{~g}$ and had type 1 duodenal atresia, for which duodenoduodenostomy was performed. There was right hand preaxial polydactyly and partial duplication of the left thumb. There were no features of Down syndrome or other organ involvement.

\section{Case 8}

A seven-month-old male infant was admitted for definitive surgery to treat Hirschsprung's disease, and had postaxial polydactyly of both the feet. There was no history of exposure to teratogens or radiation during the antenatal period. There was no other associated congenital anomaly. He had uneventful surgery for Hirschsprung's disease.

\section{Case 9}

A five-month-old female baby presented for biliary atresia surgery and had polydactyly of the right hand. There was 
a history of viral fever during the antenatal period. The mother showed a positive titer for cytomegalovirus and herpes virus. The baby was put forward to undergo Kasai surgery for biliary atresia, and the polydactyly was also excised. The baby developed progressive liver failure and died nine months after Kasai surgery.

\section{Case 10}

A six-year-old female child presented with swelling in the ventrum of the tongue and with absent lower incisor teeth since birth, with polydactyly involving both the hands and feet, and syndactyly of the left hand, with a total of 25 digits. The cardiovascular and skeletal systems were normal.

\section{Case II}

A three-month-old female baby presented with a deformity of the right upper limb and anorectal malformation. Examination showed central cyanosis with a pansystolic murmur in the precordium. There was radial thumb deformity with an absent radius and thumb, and restriction of wrist joint movements. $\mathrm{X}$-ray showed an absent radius with bowing of the ulna. The elbow joint was distorted. A rectovestibular type of anorectal malformation was present with no vertebral anomaly.

\section{Case 12}

A two-day-old male neonate, born to consanguinous parents, was brought in with deformity of both the upper limbs. Examination showed bilateral phocomelia with an absent radius and a flexion contracture of the elbow (Figure 4). There was a very small palm and hypoplastic fingers on both sides. There was hypertrichosis, a long philtrum, low-set

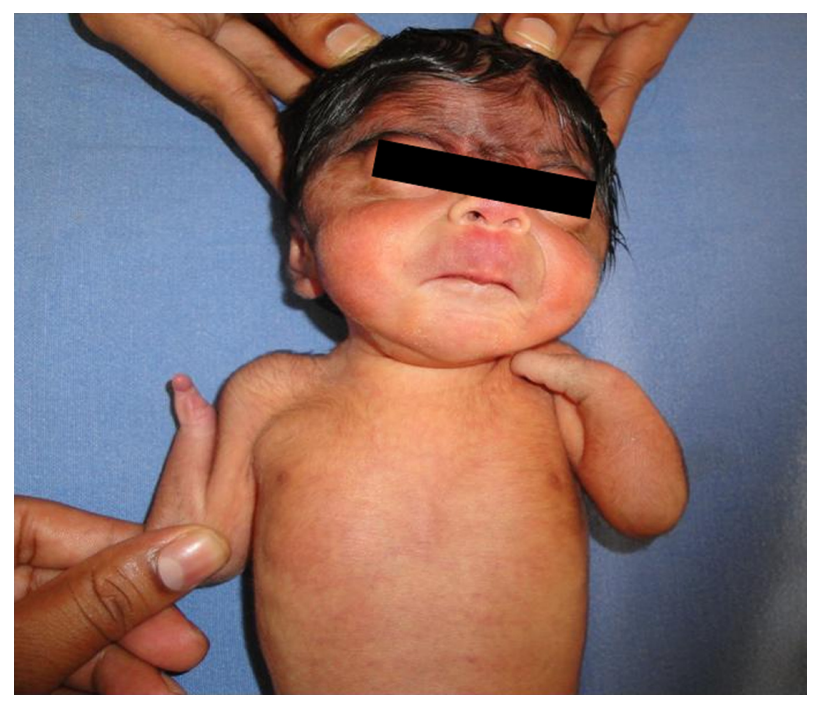

Figure 4 Upper limb phocomelia with absent radius and hands with facial deformity. ears, a short neck, and hypoplastic genitalia. These findings were consistent with Cornelia de Lange syndrome. Genetic evaluation could not be done because the parents were not willing to undergo further evaluation.

\section{Discussion}

Limb defects are common and easily recognizable birth anomalies, with an incidence of one in every 2000 live births. ${ }^{1}$ Absent limbs (amelia) without a body wall defect has an incidence of 1.5 to 2.2 per 100,000 births. ${ }^{2,3}$ When three or more minor anomalies exist in a single patient, the chance of a major anomaly is $90 \%$. These may occur as part of a recognized syndrome or as a nonsyndromic entity. Only $5 \%$ of congenital limb anomalies occur as part of recognized syndromes. Examples of syndromic conditions with limb anomalies include Holt-Oram syndrome ${ }^{4}$ (cardiac defects, upper limb defects), Fanconi syndrome (pancytopenia, limb defects, renal abnormalities, and mental retardation), TAR (thrombocytopenia with absent radius) syndrome, ${ }^{5}$ Roberts syndrome (four deficient limbs, lung hypoplasia, and cleft lip and palate), and the well-known VACTERL syndrome. Upper limbs $(70 \%-80 \%)^{6}$ are involved significantly more often than the lower limbs (42\%), and there are more rightsided defects ( $83 \%$ versus $71 \%$ ). In contrast with our study, a population-based study in Hungary from 1975 to 1984 showed equal involvement of the upper and lower limbs on both the right and left sides. ${ }^{7}$ Single limb involvement is relatively common, and constitutes $88 \%$ of cases.

The study of stillbirths with congenital anomalies provides important information regarding the spectrum of birth defects. Limb deficiencies occurring in stillbirths with congenital anomalies registered in the Health Surveillance Registry of British Columbia between the years 1964 and 1984 showed an incidence of 39.52 per 10,000 stillbirths (1:253). This incidence was significantly higher than the incidence among live births (5.97 per 10,000 live births or $1: 1842){ }^{8}$ Most cases involved the upper limbs, and most frequently the radius. Additional anomalies were present in $77 \%$ of cases compared with $48 \%$ for live births. ${ }^{8}$

Limb development takes place during weeks 3-8 of gestation. The limb buds in the Wolff crest appear as swellings on the ventrolateral aspect of the embryo. Vessels and nerves subsequently grow into the limb, along with mesodermal differentiation into cartilage and muscle to form the limb. There are various factors involved during this complex process. ${ }^{9}$ Various spectra of anomalies can occur due to any form of insult to the growing limb buds. There are many methods of classifying limb anomalies. A modification of 
the classification proposed by Swanson ${ }^{10}$ in 1968 is shown in Table 2, and is suitable for clinical description and epidemiological research. This classification gives the basic embryological error and degree of limb deformity. Failure of formation of limb buds gives rise to amelia, and longitudinal and transverse arrest of the developing limb bud gives rise to phocomelia and absent hand, respectively. The spectrum of limb reduction anomalies ranges from very mild disorders, such as syndactyly, to very severe forms, such as phocomelia or amelia. Failure of programmed cellular differentiation gives rise to syndactyly, whereas duplication gives rise to polydactyly. Amniotic constriction bands cause extrinsic pressure and lead to constriction rings and restricted growth. From the table it is clear that in any given case of limb anomaly, it is important to assess the anatomical extent of involvement first, and then identify the type of involvement, ie, absence, duplication, or any associated syndromic manifestation. Later, basic radiological imaging will give an idea of the bony picture. Other investigation may be needed to rule out other organ system involvement.

Sixty-one percent of live births with limb anomalies also had malformations of other organ systems. ${ }^{11}$ The VACTERL association has been found in $8 \%$ of cases, and $32 \%$ have structural malformations in other systems. ${ }^{12}$ The commonly associated congenital anomalies in cases with limb anomalies are anencephaly, omphalocele, renal agenesis, imperforate anus, including cloacal exstrophy and caudal regression sequences, and schisis association reflecting defects of blastogenesis. ${ }^{13}$ Our study showed other uncommonly associated conditions, including biliary atresia, Hirschsprung's disease, dentoalveolar defect, and rare syndromes like Roberts-SC syndrome and Cornelia de Lange syndrome. Preaxial limb defects occurred more frequently with microtia, esophageal atresia, anorectal atresia, heart defects, unilateral kidney dysgenesis, and some axial skeletal defects. Postaxial limb defects have hypospadias; transverse defects have craniofacial defects, micrognathia, ring constrictions, and muscular defects; intercalary defects have omphalocele; split hand/foot has encephalocele; and amelia shows anorectal atresia, omphalocele, severe genitalia defects, unilateral kidney dysgenesis, gastroschisis, and ring constriction. ${ }^{13}$ In the group with lower limb amelia, a specific pattern of associated malformations, which included omphalocele and diaphragmatic defects, was identified. ${ }^{11}$

Many etiological factors have been suggested for limb anomalies, ${ }^{14}$ which have been found to be caused

Table 2 Classification of limb anomalies

\begin{tabular}{|c|c|c|c|}
\hline Type & Anomaly & Description & Cause \\
\hline \multirow[t]{5}{*}{ Failure of formation } & Amelia & Absent limb & Failure of formation of limb bud \\
\hline & Phocomelia & $\begin{array}{l}\text { Some functional terminal } \\
\text { element of limb present, arm, } \\
\text { forearm or both absent }\end{array}$ & Intercalated longitudinal arrest \\
\hline & Absent radius/thumb & & Postaxial longitudinal arrest \\
\hline & Acheiria & Absent hand & At the carpal \\
\hline & Adactyly & Absent finger & $\begin{array}{l}\text { Transverse arrest at metacarpal } \\
\text { and phalangeal level }\end{array}$ \\
\hline \multirow[t]{2}{*}{$\begin{array}{l}\text { Failure of } \\
\text { differentiation }\end{array}$} & Syndactyly & Fused fingers/toes & $\begin{array}{l}\text { Failure of programmed cell } \\
\text { death in the seventh week }\end{array}$ \\
\hline & Camptodactyly & $\begin{array}{l}\text { Flexion deformity of proximal } \\
\text { phalanx }\end{array}$ & $\begin{array}{l}\text { Flattening of the condyle of the } \\
\text { head of the proximal phalanx, } \\
\text { aberrant lumbrical insertion }\end{array}$ \\
\hline \multirow[t]{2}{*}{ Duplication } & Polydactyly & Excess of fingers/toes & Duplication \\
\hline & Mirror hand & Ulnar duplication & \\
\hline $\begin{array}{l}\text { Constriction band } \\
\text { syndromes }\end{array}$ & Amniotic band syndrome & $\begin{array}{l}\text { Constriction ring, } \\
\text { distal deformity }\end{array}$ & $\begin{array}{l}\text { Annular bands of chorionic } \\
\text { tissue encircling the limb }\end{array}$ \\
\hline Growth defect & $\begin{array}{l}\text { Brachysyndactyly, } \\
\text { macrodacyly }\end{array}$ & Hypoplasia, hypertrophy & Undergrowth or overgrowth \\
\hline \multirow[t]{3}{*}{$\begin{array}{l}\text { Unclassified/syndromic } \\
\text { variants }\end{array}$} & Apert's syndrome & $\begin{array}{l}\text { Flat mitten hand, } \\
\text { brachicephaly, proptosis }\end{array}$ & $\begin{array}{l}\text { Acrocephalosyndactyly } \\
\text { syndrome, autosomal } \\
\text { dominant inheritance }\end{array}$ \\
\hline & Poland syndrome & $\begin{array}{l}\text { Syndactyly, pectoral } \\
\text { muscle defect, rib deficiencies, } \\
\text { brachysymphalangism }\end{array}$ & \\
\hline & Robert syndrome & $\begin{array}{l}\text { Four deficient limbs, cleft lip } \\
\text { and palate }\end{array}$ & Autosomal recessive \\
\hline
\end{tabular}


by inheritance of abnormal genes, teratogenic drugs, environmental chemicals, ionizing radiation (atomic weapons, radioiodine, and radiation therapy), infections, metabolic imbalance (eg, maternal diabetes), or mechanical factors like amniotic band syndrome. In one study, the etiology was found to be a genetic disorder in $17 \%$, environmental causes or recognized associations in $52 \%$, and unknown origin in $31 \%$ of cases. ${ }^{12}$ The most widely known teratogen causing limb reduction defects is thalidomide, ${ }^{15}$ but other limb reduction defects have been associated with prenatal exposure to hydantoin, ethanol, cocaine, and possibly mechanical vascular disruption by early chorionic villus sampling. ${ }^{16}$ With the advent of molecular genetics, genetic defects responsible for these anomalies have been recognized. Syndactyly of toes, postaxial polydactyly of the fingers, polysyndactyly, and brachydactyly were found to have a genetic basis. ${ }^{17,18}$

The most severe form, ie, tetra-amelia, characterized by complete absence of all four limbs, and associated anomalies, including craniofacial, pulmonary, and urogenital defects was found to be an autosomal recessive genetic disorder due to mutation of the WNT3 gene locus assigned to chromosome $17 \mathrm{q} 21 .{ }^{19,20}$ Researchers have found a mutation in the WNT3 gene in people with tetra-amelia syndrome from one large family. This gene is part of a family of WNT genes that play a critical role in development before birth. ${ }^{19}$ The protein produced by the WNT3 gene is involved in the formation of the limbs and other body systems during embryonic development. Mutations in the WNT3 gene prevent cells from producing functional WNT3 protein, which disrupts normal limb formation, and leads to other serious birth defects associated with tetra-amelia syndrome. ${ }^{19}$ In other affected families, the cause of tetra-amelia syndrome has not been determined. Researchers believe that unidentified mutations in WNT3 or other genes involved in limb development are probably responsible for the disorder in these cases. Among the associated pulmonary conditions observed are pulmonary hypoplasia and an abnormal pulmonary artery. Craniofacial defects include hydrocephalus, cleft lip/palate, and punctal anomalies. ${ }^{21}$ Urogenital anomalies include hypoplasia of the pelvis, malformation of the uterus, atresia of the urethra, vagina, and anus, diaphragmatic defects, and agenesis of the kidney, spleen, and adrenal glands. ${ }^{22}$ Tetra-amelia associated with facial clefts and pulmonary hypoplasia is called Roberts-SC phocomelia syndrome. ${ }^{23}$ Our tetra-amelia case showed right lung hypoplasia, hypospadias, and undescended testes, with no other anomalies.

Absence defects, preaxial polydactyly, and multiple limb deformities appeared to be sporadic. In the sporadic group, the etiological factors noted were maternal toxemia of pregnancy and illegitimate children. ${ }^{17}$ The incidence of musculoskeletal system defects among babies born to women working in a copper refinery was higher than in other occupational groups. ${ }^{24}$ Proximally placed preaxial hallucal polydactyly, particularly when coupled with segmentation anomalies of the spine and tibial hemimelia, is highly suggestive of diabetic embryopathy. ${ }^{25} \mathrm{~A}$ case-control analysis showed that lower birth weight due to intrauterine growth retardation, higher birth order, and lower socioeconomic status of parents, are more frequent in limb anomaly cases. ${ }^{7}$ Among live births in Upstate New York, various maternal characteristics examined by a case-control study in 305 cases and 915 controls born in 1970-81 showed significantly lower mean birth weight and gestation length in cases than in controls, and certain pregnancy complications (ie, abnormal vaginal bleeding and diabetes mellitus) were reported more often in cases than in controls. ${ }^{26}$ Maternal administration of a single dose of retinoic acid (vitamin A, $100 \mathrm{mg} / \mathrm{kg}$ ) has been shown to produce phocomelia or partial phocomelia in fetal mice. ${ }^{27}$ The results depended upon the time of treatment and two gradients of effect were produced, ie, a craniocaudal gradient, given that forelimb defects resulted from treatment on days 11-13, and similar hind limb abnormalities were produced by administration of retinoic acid 12-24 hours later, along with a proximodistal gradient due to the heterogeneous sensitivity of individual bones of the limb. Humeroulnar defects were produced by early treatment (11th day) and ulnoradial defects by later treatment (12th day). A similar proximodistal gradient was observed in the hind limb. ${ }^{28}$ In an interview study of 108 cases and 108 controls born in 1968-74, a history of maternal use of thyroid medication was a significant risk factor for limb anomaly. ${ }^{26}$

The spectrum of the VATER association ${ }^{29}$ has been debated ever since its first description more than two decades ago. To assess the spectrum of congenital anomalies associated with VATER, a study on infants with VATER association reported to the combined registry of infants with multiple congenital anomalies from 17 birth defects registries worldwide that are part of the International Clearinghouse for Birth Defects Monitoring Systems (ICBDMS) was performed. Of approximately 10 million infants born from 1983 through to 1991 , the ICBDMS registered 2295 infants with three or more of 25 unrelated major congenital anomalies of unknown cause. Of these infants, 286 had the VATER association, defined as at least three of the five VATER anomalies, and had significant preaxial limb anomalies. In 1969, Dieker and Opitz described the simultaneous occurrence of limb deficiencies and renal 
anomalies in three patients, and in 1972, Curran and Curran introduced the term "acrorenal syndrome" followed by Opitz postulate to explain the association by acrorenal polytopic developmental field defect concept. ${ }^{30}$

\section{Conclusion}

This observational study shows that limb anomalies are associated with many syndromic and nonsyndromic conditions. It is mandatory to evaluate patients with limb anomalies for other associated conditions. This article provides a basic understanding of limb anomalies which is necessary for appropriate evaluation, counseling, and referral of children with congenital extremity deformities.

\section{Disclosure}

The authors report no conflicts of interests in this work.

\section{References}

1. Froster-Iskenius UG, Baird PA. Limb reduction defects in over one million consecutive live births. Teratology. 1989;39:127-135.

2. Mastroiacovo P, Källén B, Knudsen LB, et al. Absence of limbs and gross body wall defects: An epidemiological study of related rare malformation conditions. Teratology. 1992;46:455-464.

3. Pilarski RT, Pauli RM, Engberg WD. Hand reduction malformations: Genetic and syndromic analysis. J Pediatr. 1985;5:274-280.

4. Basson CT, Cowley GS, Solomon SD, et al. The clinical and genetic spectrum of the Holt-Oram syndrome (heart-hand syndrome). N Engl J Med. 1994;330:885-891.

5. Hedberg VA, Lipton JM. Thrombocytopenia with absent radii. A review of 100 cases. Am J Pediatr Hematol Oncol. 1988;10:51-64.

6. Stoll C, Rosano A, Botto LD, et al. On the symmetry of limb deficiencies among children with multiple congenital anomalies. Ann Genet. 2001; 44:19-24.

7. Czeizel AE, Vitez M, Kodaj I, Lenz W. Causal study of isolated ulnarfibular deficiency in Hungary, 1975-1984. Am J Med Genet. 1993;46: 427-433.

8. Froster UG, Baird PA. Congenital defects of the limbs in stillbirths: Data from a population-based study. Am J Med Genet. 1993;46:479-482.

9. Gofflot F, Hars C, Illien F, et al. Molecular mechanisms underlying limb anomalies associated with cholesterol deficiency during gestation: Implications of Hedgehog signaling. Hum Mol Genet. 2003;12: $1187-1198$.

10. Swanson AB. A classification for congenital limb malformations. J Hand Surg Am. 1976;1:8-22.

11. Froster-Iskenius UG, Baird PA. Amelia: Incidence and associated defects in a large population. Teratology. 1990;41:23-31.

12. Evans JA, Vitez M, Czeizel A. Congenital abnormalities associated with limb deficiency defects: A population study based on cases from the Hungarian congenital malformation registry (1975-1984). Am J Med Genet. 1994;49:52-66.
13. Rosano A, Botto LD, Olney RS, et al. Limb defects associated with major congenital anomalies: Clinical and epidemiological study from the International Clearinghouse for birth defects monitoring systems. Am J Med Genet. 2000;93:110-116.

14. Tayel SM, Fawzia MM, Al-Naqeeb NA, Gouda S, Al Awadi SA, Naguib KK. A morphoetiological description of congenital limb anomalies. Ann Saudi Med. 2005;25:219-227.

15. Knobloch J, Schmitz I, Götz K, Schulze-Osthoff K, Rüther U. Thalidomide induces limb anomalies by PTEN stabilization, Akt suppression and stimulation of caspase-dependent cell death. Mol Cell Biol. 2008;28:529-538.

16. Froster UG, Baird PA. Maternal factors, medications, and drug exposure in congenital limb reduction defects. Environ Health Perspect. 1993; 101 Suppl 3:269-274.

17. Rogala EJ, Wynne-Davies R, Littlejohn A, Gormley J. Congenital limb anomalies: Frequency and aetiological factors. Data from the Edinburgh register of the newborn (1964-68). J Med Genet. 1974;11:221-233.

18. Dewan P, Agarwal N, Dewan P, Batta V. Familial crossed polysyndactyly in four generations of an Indian family. World J Pediatr. 2010; 6:177-180.

19. Niemann S, Zhao C, Pascu F, et al. Homozygous WNT3 mutation causes tetra-amelia in a large consanguineous family. Am J Hum Genet 2004;74:558-563.

20. Basaran S, Yuksel A, Ermis H, Kuseyri F, Agan M, Yuksel-Apak M. Tetra-amelia, lung hypo-/aplasia, cleft lip-palate, and heart defect: A new syndrome? Am J Med Genet. 1994;51:77-80.

21. Temtamy SA, Loutfi AH. Some genetic and surgical aspects of the cleft lip-cleft palate problem in Egypt. Cleft Palate J. 1970;7:578-594.

22. Rosenak D, Ariel I, Arnon J, et al. Recurrent tetra-amelia and pulmonary hypoplasia with multiple malformations in sibs. Am J Med Genet. 1991; 38:25-28.

23. De Ravel TJ, Seftel MD, Wright CA. Tetra-amelia and splenogonadal fusion in Roberts's syndrome. Am J Med Genet. 1997;68:185-189.

24. Vaktskjold A, Talykova LV, Chashchin VP, Odland JO, Nieboer E. Maternal nickel exposure and congenital musculoskeletal defects. Am J Ind Med. 2008;51:825-833.

25. Adam MP, Hudgins L, Carey JC, et al. Preaxial hallucal polydactyly as a marker for diabetic embryopathy. Birth Defects Res A Clin Mol Teratol. 2009;85:13-19.

26. Polednak AP, Janerich DT. Maternal factors in congenital limb-reduction defects. Teratology. 1985;32:41-50.

27. Rizzo R, Lammer EJ, Parano E, Pavone L, Argyle JC. Limb reduction defects in humans associated with prenatal isotretinoin exposure. Teratology. 1991;44:599-604.

28. Kwasigroch TE, Kochhar DM. Production of congenital limb defects with retinoic acid: Phenomenological evidence of progressive differentiation during limb morphogenesis. Anat Embryol (Berlin). 1980;161:105-113.

29. Solomon BD, Pineda-Alvarez DE, Raam MS, Cummings DA. Evidence for inheritance in patients with VACTERL association. Hum Genet. 2010;127:731-733.

30. HesterYK, Richard SO, Aldo R, et al. Renal defects and limb deficiencies in 197 infants: Is it possible to define the "acrorenal syndrome"? Am J Med Genet. 2004;129:149-155.

\section{Dovepress}

\section{Publish your work in this journal}

Pediatric Health, Medicine and Therapeutics international, peerreviewed, open access journal publishing original research, reports, editorials, reviews and commentaries. All aspects of health maintenance, preventative measures and disease treatment interventions are addressed within the journal. Practitioners from all disciplines are invited to submit

their work as well as healthcare researchers and patient support groups. The manuscript management system is completely online and includes a very quick and fair peer-review system. Visit http://www.dovepress. $\mathrm{com} /$ testimonials.php to read real quotes from published authors. 